\title{
UNSUR-UNSUR PARAGRAF NARASI DALAM BAHASA JAWA
}

\begin{abstract}
Sri Nardiati*
ABSTRACT

Every human being involves in story activity. Therefore, the elements of NP (narrative paragraph) in Javanese should be investigated. The aim of investigation is to describe every element based on the character and the chronological event, its direct utterance, and the writer's point of view. The scope of narrative paragraph study covers lingual unit of paragraph, sentence, clause, phrase, and word. The approach used is structural descriptive. The data is obtained by using listening and noting technique. The analysis uses orthografic method and distributional method, by using direct element division technique and then omission, substitution, insertion, and reversion. Narrative paragraph (NP) elements are participant and event. Participant element is filled with a character or more. Event element comprises of act, process, or state verb that relates to each other as stimulus-responsse. NP usually has direct utterance that is unmarked and marked. The mark is located in the beginning, middle, and the ending. NP is written based on the point of view, both the first and third person. In the first point of view, the character is central character or an observer, which is marked by using I (aku, saya) pronoun; meanwhile, in the third person point of view is marked by he/ she (ia/dia/dheweke) pronoun.
\end{abstract}

Keywords: event, narrative paragraph, paragraph, participant, topic/main idea

\begin{abstract}
ABSTRAK
Setiap manusia terlibat dalam aktivitas cerita. Untuk itu, unsur-unsur paragraf narasi (PN) dalam bahasa Jawa perlu diteliti. Tujuannya ialah mendeskripsikan berbagai unsur berdasarkan tokoh dan urutan peristiwanya, tuturan langsungnya, dan sudut pandang penulisnya. Ruang lingkup kajian PN ini mencakupi satuan lingual paragraf, kalimat, klausa, frasa, dan kata. Pendekatan yang digunakan ialah deskriptif struktural. Data dikumpulkan dengan metode simak, teknik catat. Analisisnya menggunakan metode padan ortografis dan metode agih dengan teknik bagi unsur langsung dilanjutkan dengan teknik lesap, ganti, sisip, dan balik. Unsur PN berupa partisipan dan peristiwa. Unsur partisipan diisi dengan satu tokoh atau lebih. Unsur peristiwa diisi dengan verba aksi, proses, dan keadaan yang berhubungan sebagai stimulus-respons. PN cenderung bertuturan langsung, baik yang tidak berpenanda maupun yang berpenanda. Penanda ini berposisi di awal, tengah, dan akhir. PN ditulis berdasarkan sudut pandang, baik orang pertama maupun orang ketiga. Dalam sudut pandang orang pertama, tokoh menjadi sentral atau pengamat yang ditandai dengan penggunaan pronomina $a k u$ 'saya, aku', sedangkan di dalam sudut pandang orang ketiga ditandai dengan pronomina 'dheweke'ia/dia.
\end{abstract}

Kata Kunci: paragraf, paragraf narasi, partisipan, peristiwa, topik/gagasan pokok

* Balai Bahasa Provinsi Daerah Istimewa Yogyakarta 


\section{PENGANTAR}

Di dalam tulisan ini dikaji masalah unsurunsur paragraf narasi (PN) dalam bahasa Jawa. Penelitian ini merupakan bagian dari penelitian yang berjudul "Paragraf dalam Bahasa Jawa: Konstruksi dan Permasalahannya" oleh Nardiati dkk. (2013). Terkait dengan hal itu, ada dua istilah penting yang perlu diketahui konsepnya, yakni istilah paragraf dan narasi. Paragraf merupakan satuan kebahasaan terkecil dari karangan (Tarigan, 1986). Adapun yang dimaksud dengan narasi adalah suatu bentuk karangan yang berusaha mengisahkan suatu kejadian atau peristiwa, seolah-olah pembaca melihat atau mengalami sendiri peristiwa itu (Keraf, 1982:136). Jadi, yang dimaksud paragraf narasi adalah satuan kebahasaan berupa kelompok kalimat yang berisi kisah atau cerita suatu kejadian atau peristiwa.

Setiap manusia pasti terlibat dalam aktivitas bercerita, baik lisan secara langsung maupun tulis secara tidak langsung atau sebagai pelaku atau sebagai penerima atau penikmat. Tentu saja, satuan lingual yang berupa PN ini penting dalam komunikasi karena aktivitas cerita dibangun dari rangkaian kalimat atau kelompok kalimat berupa paragraf. Untuk itu, berbagai aspek yang terdapat pada paragraf narasi dalam bahasa Jawa perlu dideskripsikan.

Sepanjang pengetahuan penulis, hasil penelitian sebelumnya yang terkait dengan paragraf narasi belum dilakukan. Namun, sudah dilakukan penelitian yang terkait dengan wacana narasi dalam bahasa Jawa. Penelitian pertama dilakukan oleh Sumadi dkk. (1998) dengan judul Kohesi dan Koherensi dalam Wacana Naratif Bahasa Jawa. Penelitian kedua dilakukan oleh Indiyastini dkk. (2003) dengan judul "Wacana Naratif dalam Bahasa Jawa". Penelitian ketiga dilakukan oleh Wedhawati dkk. (2008) dengan judul "Wacana Narasi Bahasa Jawa". Objek penelitian dari ketiga penelitian tersebut berupa wacana, yaitu satuan kebahasaan terbesar atau tertinggi yang disusun berdasarkan pola pengorganisasian beruntun (horizontal) dan hierarkis (vertikal) (Hinds dalam Givon (ed.),
1979:135). Wacana diwujudkan ke dalam karangan yang utuh.

Konsep wacana tersebut berbeda dengan konsep paragraf. Paragraf adalah satuan kebahasaan berupa kelompok kalimat yang menjadi bagian dari karangan, bersifat satu, padu, logis, dan sistematis. Setiap satu paragraf hanya terdapat satu gagasan pokok. Hubungan antara pernyataan yang satu dan yang lainnya harus padu dan logis. Gagasan pada paragraf dikemukakan secara sistematis. Dengan demikian, jelas bahwa lingkup kajian wacana narasi berbeda dengan paragraf narasi. Untuk itu, penelitian yang terkait dengan paragraf narasi dalam bahasa Jawa perlu dilakukan.

Hasil penelitian ini bermanfaat, baik secara teoretis maupun secara praktis. Secara teoretis, hasil penelitian ini dapat melengkapi teori tentang paragraf dalam bahasa Jawa, sedangkan secara praktis, hasil penelitian ini dapat digunakan sebagai bahan penyusunan buku pembinaan atau pembelajaran bahasa Jawa.

Paragraf merupakan kumpulan kalimat yang membangun gugus proposisi. Setiap paragraf terdiri atas satu gagasan pokok yang diwujudkan ke dalam kalimat topik sebagai proposisi inti dan gagasan penjelas yang diwujudkan ke dalam kalimat penjelas sebagai proposisi bawahan (Montolalu, 1988:5). Selanjutnya, Ramlan (1993) menyebutkan bahwa dalam paragraf ada dua aspek yang harus diperhatikan, yaitu (1) alur pikiran dan (2) kepaduan paragraf (kepaduan bentuk dan makna).

Kisahan atau narasi merupakan jenis paragraf penceritaan atas dasar pengamatan atau perekaan (Moeliono, 1989:124). Narasi berciri (1) berorientasi pada tokoh (Grimes, 1975:261). Rangkaian perbuatan bersifat logis, melahirkan kausalitas atau sebab-akibat. Tuturantuturan atau pernyataan di dalamnya memiliki hubungan khronologis, berstruktur stimulusresponss (Montolalu, 1988:21). Tuturan-tuturan itu mempunyai hubungan rangkaian waktu atau time sequence (Peter, 1977:73). Narasi berisi kisah kejadian atau peristiwa yang terjadi dalam suatu 
rangkaian waktu (Keraf, 1992:136).

Dalam narasi, partisipan atau tokoh menjadi satu kesatuan dengan tuturan yang menyatakan peristiwa (Grimes, 1975:43-50). Unsur tokoh merupakan faktor yang perlu diperhitungkan dalam suatu perbuatan (Keraf, 1996:157). Unsur yang menonjol dalam teks narasi ialah mempunyai hubungan logis, berstruktur stimulus-respons (Montolalu, 1988:21). Konstituen yang berfungsi sebagai stimulus berada pada urutan sebelah kiri dan konstituen perespons berada di sebelah kanan.

Dalam narasi yang perlu diperhitungkan ialah unsur atau faktor (karakter) tokoh, perbuatan, dan sudut pandang. Rangkaian perbuatan atau tindakan oleh tokoh membangun kesatuan makna paragraf. Hal tertentu selalu mengakibatkan hal yang lebih besar, semuanya bersama-sama menunjang titik sentral perbuatan (Keraf, 1992:159).

Wacana narasi biasanya bertopik persona yang dapat disubstitusi dengan pronomina persona (ia, dia, mereka, dan sebagainya) (Baryadi, 1993:13). Dalam narasi, topik nonpersona akan mengalami personifikasi (Baryadi, 1993:14). Topik persona dalam narasi akan menghadirkan komen yang berwujud verba aksi, keadaan, atau proses (Tampubolon, 1979).

Keberadaan sebuah topik pada narasi sangatlah penting. Satuan lingual yang menjadi topik berposisi pada awal kalimat pertama dan satuan lingual yang menjadi komen mengikutinya (Baryadi, 2002:57). Dalam keadaan netral, satuan lingual yang menjadi topik sebagai subjek. Posisinya mendahului kata kerja pengisi predikat dalam kalimat (Poedjosoedarmo dkk., 1981:31). Dalam kaitannya dengan pola organisasi informasi, topik merupakan suatu informasi yang lebih penting. Kenyataan ini sejalan dengan gagasan bahwa bahasa Jawa merupakan bahasa penampil topik (topic prominent language) (Sukesti, 2004:221).

Sebagaimana lazimnya, sebuah penelitian menggunakan tiga tahapan proses, yakni cara atau metode penyediaan data, cara atau metode analisis atau pengolahan data, cara atau metode pemaparan hasil analisis atau pengolahan data (Sudaryanto,
1982:7; 1986, 1992:57 dalam Kesuma, 2009:16). Pengumpulan data pada penelitian ini digunakan metode simak terhadap satuan lingual yang tergolong paragraf narasi dalam bahasa Jawa. Teknik yang digunakan ialah teknik simak bebas libat cakap. Teknik ini dilanjutkan dengan teknik catat, yaitu dilakukannya pencatatan sebagai hasil penyimakan (Kesuma, 2009:18).

Di dalam tahap analisis digunakan metode padan ortografis (Kesuma, 2009:19). Dengan metode ini peneliti berusaha mengidentifikasi data berupa paragraf narasi dari sumber kisahan yang berjenis fiksi. Selain itu, pada analisis data digunakan metode agih (Sudaryanto, 1993:15) karena semua alat penentunya berada dalam bahasa yang diteliti. Sebagai contoh, data yang berbahasa Jawa ini ditentukan dengan bahasa Jawa itu sendiri.

Dalam analisis digunakan teknik dasar dan lanjutan. Teknik dasar diwujudkan melalui teknik bagi unsur langsung, sedangkan teknik lanjutan diwujudkan melalui teknik lesap, teknik ganti, teknik perluas, teknik sisip, teknik balik, teknik ubah wujud, teknik ulang, teknik baca markah, dan teknik pemerkuat (Kesuma, 2009:21). Akhirnya, hasil analisis data itu disusun menjadi laporan hasil penelitian dengan metode penyajian informal, yaitu perumusan dengan kata-kata sebagai mana lazimnya.

Data dalam penelitian ini ialah bahasa Jawa ngoko dan krama beragam umum yang digunakan dalam berbagai media massa cetak, misalnya, majalah dan novel berbahasa Jawa: Penjebar Semangat (PS), Jaya Baya (JB), Jaka Lodang $(J L)$, novel Kinanti (K), Kembang Kanthil (KK), Mungsuh Mungging Cangklakan (MMC), dan Kumpule Balung Pisah (KBP). Dari salah satu sumber tersebut terdapat data paragraf narasi sebagai berikut.

(1) (a) Kawiwitan saka pabrik papanku digawe nganti tekan titi wanci iki, sewu pengalaman wis dakliwati. (b) Bener, aku pancen mung sepatu, mung sepatu. (c) Nanging aku kalebu sepatu eksklusif. (d) Aku digawe saka kulit pinilih lan diwangun kanthi caklrik elegant lan gagah. (Panjebar Semangat, No. 33, 15 
Agustus 1998:28)

(a) Dimulai dari pabrik tempat pembuatanku sampai dengan saat sekarang ini, seribu pengalaman sudah kulalui. (b) Benar, aku memang hanya sepatu, hanya sepatu. (c) Namun, aku tergolong sepatu eksklusif. (d) Aku dibuat dari kulit terpilih dan dibentuk dengan model elegan dan gagah.'

PN (paragraf narasi) tersebut dibangun atas empat kalimat dari (a)-(d) sebagai proposiproposisinya dengan ide pokok atau gagasan pokok berupa kalimat (b) aku pancen mung sepatu. 'Aku memang hanya sepatu.' sebagai pernyataan umum yang berada di tengah paragraf. Gagasan pokok tersebut dikembangkan dengan gagasan-gagasan penjelas yang berada pada urutan sebelah kiri dan kanannya melalui kalimat-kalimat penjelas (a), (c), dan (d).

Setiap proposisi PN tersebut terdiri atas unsur tokoh sebagai partisipan dan unsur perbuatan sebagai peristiwanya. Unsur partisipannya berupa satuan lingual $a k u$ 'saya' yang dipersonifikasi menjadi sepatu. Unsur yang lain berupa urutan peristiwa yang terjadi dalam satu rangkaian waktu. Peristiwa yang satu dan yang lainnya berhubungan sebagai stimulus-respons.

Berdasarkan sudut pandang yang digunakannya, PN (1) bersudut pandang O1 sebagai tokoh utama atau sentral. Sudut pandang ini ditandai dengan hadirnya satuan lingual pronomina aku 'saya' yang sering diwujudkan dengan klitika $-k u$ atau prefiks dak-. Dalam penceritaannya, PN cenderung berunsur tuturan langsung. Namun, pada contoh yang ditampilkan tersebut tidak terdapat tuturan langsung.

Berdasarkan contoh (1) tersebut, pembahasan pada tulisan ini meliputi unsur pembangun paragraf narasi $(\mathrm{PN})$, unsur penanda tuturan langsung paragraf narasi, dan unsur yang berupa sudut pandang penulis paragraf narasi. Berikut ini ketiga pokok soal tersebut dipaparkan.

\section{UNSUR PARTISIPAN PARAGRAF NARASI}

Dalam PN terdapat satu tokoh atau lebih sebagai partisipannya. Jika ada partisipan yang hanya diisi dengan satu tokoh, partisipan itu biasanya berstatus sebagai gagasan pokok, yaitu sesuatu yang dibicarakan. Partisipan ini melakukan serangkaian perbuatan logissistematis seperti yang tertera pada $\mathrm{P}$ kalimat sehingga tersusun paragraf yang maknanya padu. Contohnya sebagai berikut.

(2) (a) Watik mlebu ngomah terus nguncalake tase. (b) Dheweke banjur nggloso ing dhipan sing kasure empuk lan sepreine rupa ijo rinoncen gambar kembang. (PS, No. 40, 1 Oktober 1994:38)

(a) Watik masuk rumah lalu melemparkan tasnya. (b) Ia terus merebahkan dirinya di atas dipan yang berkasur empuk dan berseprei warna hijau bergambar rangkaian bunga.'

(3) (a) Dina Minggu esuk katon ana sedhan biru metu saka kutha Sala. (b) Lakune alon, mesine prasasat tanpa swara, nlusur dalan mangetan ngener Gunung Lawu. (c) Jurug, Palur, Tasikmadu, Karanganyar, munggah terus. (Panjebar Semangat 33, 15 Agustus. 1998:28)

(a) Hari Minggu pagi tampak ada sedan biru keluar dari kota Sala. (b) Jalannya pelan, mesinnya hampir tidak bersuara, menyusuri jalan ke arah timur menuju Gunung Lawu. (c) Jurug, Palur, Tasikmadu, Karanganyar, naik terus.'

(4) (a) Pak Jamil gegancangan menyang mobil, $\varnothing$ mbukakake lawang kanggo eyang Pana. (b) Aku lungguh ing mburi lan Ø ngawasake mobile Bu Aminoto kang disopiri dening wong lanang lemu isih enom. (Kinanti:204)

(a) Pak Jamil bergegas menuju mobil, Ø membukakan pintu untuk eyang Pana. (b) Saya duduk di belakang dan $\varnothing$ memandangi mobil $\mathrm{Bu}$ Aminoto yang disopiri oleh pria gemuk masih muda.'

Dalam contoh (2) terdapat satu tokoh sebagai partisipannya. Unsur tersebut berkategori nomina Watik 'nama wanita' sebagai pengisi gagasan utama. Begitu pula pada contoh (3) terdapat satu tokoh yang dipersonifikasi berkategori frasa nominal sedhan biru 'sedan biru' sebagai pengisi gagasan pokok. Nomina insani Watik dan nomina noninsani sedhan biru yang berstatus sebagai topik itu dipertahankan melalui penggantian, pelesapan, dan penunjukan. Hal itu berbeda dengan 
contoh (4) yang terdapat lima tokoh sebagai partisipannya. Kelima tokoh itu ialah Pak Jamil dan eyang Pana pada (4a); aku 'saya', mobile Bu Aminoto 'mobil Bu Aminoto', dan wong lanang lemu isih enom 'orang laki-laki gemuk masih muda' pada (4b) sebagai partisipannya.

Dalam contoh (2)-(4) terdapat proses penggantian, perujukan, dan pelesapan. Penggantian tampak pada pronominal dheweke (2b) yang bereferen sama dengan Watik (2a). Pelesapan unsur Watik tampak di antara unsur terus 'terus' dan nguncalake 'melemparkan' (2a). Pelesapan unsur sedhan biru 'sedan biru' tampak pada urutan sebelah kiri unsur nlusur 'menelusur' (3b) dan urutan sebelah kiri unsur munggah 'naik' (3c). Pelesapan unsur Pak Jamil terjadi pada urutan sebelah kiri unsur mbukakake 'membukakan' (4a) dan unsur aku 'saya' di sebelah kiri ngawasake 'memandangi' pada 4b).

Penunjukan tampak pada penggunaan satuan lingual - $e$ pada tase 'tasnya' (2a) dan lakune 'jalannya' yang merujuk pada unsur Watik. Penunjukan yang menggunakan unsur - $e$ tampak pula pada mesine (3b) yang merujuk pada sedhan biru (3a). Unsur-unsur tersebut dapat dimunculkan ke permukaan sehingga kepaduan makna paragraf semakin nyata, seperti berikut.

(2a) (a) Watik mlebu ngomah terus Watik nguncalake tase. (b) Dheweke banjur nggloso ing dhipan sing kasure empuk lan sepreine rupa ijo rinoncen gambar kembang.

(a) Watik masuk rumah lalu Watik melemparkan tasnya. (b) Ia terus merebahkan dirinya di atas dipan yang berkasur empuk dan berseprei warna hijau bergambar rangkaian bunga.'

(3a) (a) Dina Minggu esuk katon ana sedhan biru metu saka kutha Sala. (b) Lakune sedhan biru alon, mesine sedhan biru prasasat tanpa swara, sedhan biru nlusur dalan mangetan ngener Gunung Lawu. (c) Jurug, Palur, Tasikmadu, Karanganyar, sedhan biru munggah terus. (Penjebar Semangat, No. 33, 15 Agustus 1998:28)

(a) Hari Minggu pagi tampak ada sedan biru keluar dari kota Sala. (b) Jalannya sedan biru pelan, mesinnya sedan biru hampir tidak bersuara, sedan biru menyusuri jalan ke arah timur menuju Gunung Lawu. (c) Jurug, Palur, Tasikmadu, Karanganyar, sedan biru naik terus.'

(4a) (a) Pak Jamil gegancangan menyang mobil, Pak Jamil mbukakake lawang kanggo eyang Pana. (b) Aku lungguh ing mburi lan aku ngawasake mobile Bu Aminoto kang disopiri dening wong lanang lemu isih enom. (Kinanti:204)

(a) Pak Jamil bergegas menuju mobil, Pak Jamil membukakan pintu untuk eyang Pana. (b) Saya duduk di belakang dan saya memandangi mobil $\mathrm{Bu}$ Aminoto yang disopiri oleh pria gemuk masih muda.'

Uraian tersebut menguatkan bahwa unsur tokoh sangatlah penting karena keberadaannya berinisiasi untuk melakukan perbuatan sebagai peristiwanya. Kehadiran unsur tersebut dipertahankan pada kalimat-kalimat penjelas dengan pelesapan, penunjukan, penggantian, dan pengulangan. Dengan menggunakan teknik tersebut, tingkat kekohesifan dan kekoherensifan menjadi tinggi.

\section{UNSUR PERISTIWA PARAGRAF NARASI}

Unsur peristiwa pada PN diisi dengan kategori verba, baik verba keadaan, perbutan, maupun verba proses. Semua peristiwa itu dilakukan dan dialami oleh tokoh yang menjadi partisipannya. Perbuatan yang dilakukan dan dialami ini bersifat logis dalam satu rangkaian waktu. Semua perbuatan dan keadaan itu sebagai pengisi $\mathrm{P}$ klausa induk atau proposisi utama kalimat yang bersangkutan. Contohnya sebagai berikut.

(5) (a) Mbok Arja terus metu ing ruwang tamu sing swasanane peteng jalaran lampune dipateni. (b) Karo miyak kordhen Mbok Arja nginjen sapa tamune. (c) Bareng wis ngerti yen sing teka wong wadon lemu kathokan dawa, dheweke banjur nuju nyang kamare ndarane. (Penjebar Semangat 401 Okt. 1994:38)

(a) Bok Arja terus keluar menuju ruang tamu yang suasananya gelap karena lampunya mati. (b) Sambil membuka gorden Bok Arja mengintip siapa tamunya. (c) Setelah 
mengerti kalau yang datang wanita gemuk bercelana panjang, ia lalu menuju kamar majikannya.'

(6) (a) Wong-wong padha megeng napas. (b) Pak Amat Usup nggrayang otot ketege, kabeh wis padha siyaga ambiyantu. (c) Lurah Darmin ora bisa ngucap, mapane lungguh ana penere sirah. (d) Harjita kaya tugu. (e) Mripate Supini melek maneh tumenga kaya ana sing dipandeng lan lambene umak-umik kaya lagi ana sing diucapake, wusana banjur les ... merem. (Kembang Kanthil, 1957)

(a) Semua orang menahan nafas. (b) Pak Amat Usup meraba urat nadinya, semua sudah siaga membantu. (c) Lurah Darmin tidak dapat mengucap, tempat duduknya tepat lurus dengan kepala. (d) Harjita diam bagai tugu. (e) Mata Supini terbuka lagi menengadah seperti ada yang dipandang dan bibirnya komat-kamit seperti ada yang diucapkan, akhirnya terus ... terpejam.'

(7) (a) Partadikrama kekah nampik, Sumardi boten purun ngawon, malah ing wekasanipun lajeng adora-cara, ngaken bilih arta sampun katampekaken dhateng Abdulsukur sadaya. (b) Partadikrama ... sangsaya judheg. (Mungsuh Mungging Cangklakan, 1929: ...)

(a) Partadikrama tetap menolak, Sumardi tidak mau mengalah, malahan pada akhirnya berbohong, mengaku kalau uang sudah diterimakan kepada Abdulsukur semua. (b) Partadikrama ...semakin sedih.'

Dalam PN (5) digunakan dua tokoh sebagai partisipannya, yaitu Bok Arja 'Bu Arja' pada (5a) dan (5b), serta wong wadon lemu kathokan dawa 'wanita gemuk bercelana panjang' pada (5c). Dari kedua partisipan ini yang membangun inisiasi hanya satu, ialah Bok Arja 'Bu Arja'. Tokoh tersebut dalam keadaan terus metu 'terus keluar' pada (5a), melakukan perbuatan nginjen 'mengintip' pada (5b), dan banjur nuju 'terus menuju' pada $(5 \mathrm{c})$. Keadaan dan perbuatan itu terjadi secara kronologis dan dilakukan oleh tokoh yang menjadi partisipannya dalam satu rangkaian waktu.

Dalam PN (6) terdapat lima tokoh yang menjadi partisipannya, yaitu wong-wong 'semua orang’ pada (6a), Pak Amat Usup pada (6b), kabeh 'semua' pada (6b), Lurah Darmin pada (6c), Harjita pada (6d), dan Mripate Supini 'mata supini' (6e). Tokoh wong-wong (6a) dalam keadaan padha megeng napas 'bersama-sama menahan nafas'. Tokoh Pak Amat Usup pada (6b) melakukan perbuatan nggrayang 'meraba'. Partisipan kabeh 'semua orang' melakukan perbuatan siyaga ambiyantu 'siap membantu'. Tokoh Lurah Darmin pada (6c) dalam keadaan ora bisa ngucap 'tidak dapat berkata' dan ana 'berada'. Tokoh Harjito pada (6d) dalam keadaan kaya tugu 'menyerupai tugu'. Tokoh Supini 'Supini' pada (6e) dalam keadaan melek maneh tumenga 'terbuka (mata) lagi menengadah', umak-umik 'berkomat-kamit', dan les ...merem 'terpejam'. Semua keadaan yang dialami dan perbuatan yang dilakukan tokoh yang menjadi partisipan itu bersifat logis berdasarkan satu rangkaian waktu.

Dalam PN (7) terdapat dua tokoh sebagai partisipannya, yaitu Partadikrama dan Sumardi. Tokoh Partadikrama melakukan perbuatan kekah nampik 'kukuh menolak' yang dinyatakan pada (7a). Tokoh Sumardi melakukan perbuatan boten purun ngawon 'tidak mau mengalah' dan lajeng adora-cara 'bertipu muslihat' dan ngaken bilih arta sampun katampekaken 'terus berdusta bahwa uang sudah diterimakan' yang dinyatakan pada (7a). Akhirnya, tokoh Partadikrama dalam keadaan sangsaya judheg 'semakin sedih' yang dinyatakan pada (7b). Peristiwa tersebut terjadi secara logis dalam satu rangkaian waktu.

\section{SUDUT PANDANG PENGARANG DALAM PARAGRAF NARASI}

Sudut pandang pengarang pada PN ada dua, yaitu sudut pandang pengarang sebagai orang pertama dan sudut pandang orang ketiga. Sudut pandang pengarang dalam PN dibedakan menjadi dua, yaitu sudut pandang pengarang sebagai tokoh sentral yang lazim disebut sudut pandang orang pertama dan sudut pandang pengarang sebagai pengamat. 


\section{Sudut Pandang Orang Pertama (01)}

Sebagaimana sudah disebutkan bahwa di dalam PN yang bersudut pandang orang pertama dapat dipilah menjadi dua. Pertama, pengarang atau narator menyatukan diri dengan karyanya sebagai tokoh sentral dengan tokoh utama yang lazim menggunakan pronomina $a k u$. Kedua, pengarang atau narator berada di luar, ia berstatus sebagai pengamat sehingga namanya tidak tergambar di dalam karangan.

\section{Sudut Pandang Orang Pertama sebagai Tokoh Sentral}

Dalam hal ini, seorang pengarang atau narator melibatkan diri sebagai tokoh sentral dengan nama $a k u$. Kata ganti orang pertama $a k u$ dapat berwujud klitik $-k u$ pada satuan lingual lain. Contohnya sebagai berikut.

(8) (a) Sapa wae ora kena nyepelekake aku. (b) Pancen aku mung sepatu. (c) Mung sepatu. (d) Nanging eling, sepisan maneh eling. (e) Senajan mung sepatu, aku dudu sepatu murahan. (f) Aku sepatu eksklusif. (g) Regane seprapat yuta. (h) Bendaraku sawijine manajer ing perusahaan kondhang. (i) Mula sabaku ing hotel-hotel, rumah-rumah makan, lan ing papan-papan sing sarwa resik. (Penjebar Semangat 33-15 Agst. 1998:29)

'(a) Semua orang tidak boleh menyepelekan aku. (b) Memang aku hanyalah sepatu. (c) Hanya sepatu. (d) Tapi ingat, sekali lagi ingat. (e) Meski hanya sepatu, aku bukan sepatu murahan. (f) Aku sepatu eksklusif. (g) Harganya seperempat juta. (h) Majikanku seorang manajer di perusahaan yang terkenal. (i) Makanya keberadaanku di hotel-hotel, rumah-rumah makan, dan di tempat-tempat yang bersih.'

Tokoh sentral paragraf (8) tersebut ialah pronomina orang pertama aku. Satuan lingual aku 'saya' tampak pada (8a) Sapa wae ora kena nyepelekake aku, pada (8b) Pancen aku mung sepatu, pada (8e) Aku dudu sepatu murahan, dan pada (8f) $\boldsymbol{A} \boldsymbol{k} \boldsymbol{u}$ sepatu eksklusif. Selain itu, tokoh $\boldsymbol{a} \boldsymbol{k} \boldsymbol{u}$ tampak sebagai klitik-ku pada (8h) Bendaraku sawijine manajer ing perusahaan kondhang dan (8i) Mula sabaku ing hotel-hotel. Dari uraian tersebut, jelas bahwa pada paragraf
(8) digunakan sudut pandang orang pertama aku sebagai tokoh sentral.

\section{Sudut Pandang Orang Pertama sebagai Pengamat}

Di dalam paragraf narasi ini sang pengarang atau narator sebagai pengamat. Ia berada di luar teks mengamati berbagai peristiwa yang dilakukan atau keadaan yang dialami oleh tokoh sebagai partisipannya. Oleh karena itu, satuan lingual yang merujuk pada pengarang atau narator tidak tergambar dalam proses penceritaan. Contohnya sebagai berikut.

(9) (a) Ana kantor sing katon mung Mbak Nur karo Mbak Vina lagi ngadhep komputer. (b) Wiwit anane BOS, BOPDA, sarta sertifikasi iki, karyawan TU loro iku kaya ora kober leren. ... (e) Amarga swasana kang semanak ing pamulangan iki, karyawan loro kang isih honorer iku betah, mulih nganti sore. (Penjebar Semangat No. 42-16 Okt. 2010:24)

(a) Di kantor yang ada hanya mbak Nur dan mbak Vina sedang menghadap ke komputer. (b) Sejak adanya BOS, BOPDA, serta sertifikasi, karyawan TU dua itu seakan tak sempat lagi beristirahat. ... (e) Karena suasana yang familier di sekolah ini, karyawan dua yang masih honorer itu betah, kerasan sampai sore.'

Pada paragraf narasi (9) digunakan dua nama tokoh, yaitu Mbak Nur dan Mbak Vina sebagai partisipannya. Kedua nama tokoh ini digunakan sebagai pelaku atau pengalam dalam penceritaan oleh pengarang. Dalam proses penceritaan, kedua nama tokoh itu menjalankan perbuatan sebagai peristiwa atau mengalami keadaan seperti yang tersebut pada predikat klausa induk setiap kalimat yang bersangkutan. Pada paragraf (9), pengarang berada di luar proses penceritaan. Ia hanya berstatus sebagai pengamat, tidak terlibat sebagai tokoh baik sentral maupun bawahan.

\section{Sudut Pandang Orang Ketiga (03)}

Dalam hal ini pengarang atau narator memusatkan perhatiannya pada karakter orang ketiga sebagai tokoh sentral. Paragraf narasi bersudut pandang orang ketiga ini ditandai dengan penggunaan kata ganti orang ketiga dheweke. 
Perhatikan contoh berikut.

(10) (a) Saben arep nulis jenenge dhewe, tangane mesthi kesleo lan sing katulis tembung "babi". (b) Dheweke dadi mangkel banget. (c) Wis tau dheweke nekani salah sawijing ahli ilmu jiwa, nanging ora oleh asil. (d) Dheweke uga wis tau menyang sawenehing alim ulama, nanging dheweke mung dituturi supaya istirahat. (Penjebar Semangat Crita Cekak "Babi":28)

(a) Setiap akan menulis namanya, tanganya pasti terkilir dan yang tertulis kata "babi". (b) Ia menjadi mengkal sekali. (c) Sudah pernah ia mendatangi salah seorang ahli ilmu jiwa, tetapi tidak mendapatkan hasil. (d) Ia juga sudah pernah ke salah seorang ulama, tetapi ia hanya diberi saran agar beristirahat.'

Di dalam paragraf narasi (10) pengarang atau narator memfokuskan perhatiannya pada karakter orang ketiga dengan menggunakan kata ganti dheweke 'ia'. Satuan lingual kata ganti orang ketiga dheweke 'ia' dipilih pengarang menjadi partisipan untuk melakukan perbuatan atau mengalami keadaan seperti yang tersebut pada predikat klausa induk pada kalimat yang bersangkutan. Kategori verba atau frasa verbal dadi mangkel 'menjadi mengkal' pada (10b), menyang sawenehing alim ulama 'ke seorang ulama' pada (10c), mung dituturi 'hanya disarankan' pada (10d), dan verba nekani 'mendatangi' pada (10c) merupakan perbuatan atau aktivitas yang dilakukan oleh dheweke sebagai pelakunya yang disebutkan pada (10b) dan (10c). Pronomina ini mempunyai rujukan yang sama dengan satuan lingual jenenge dhewe 'namanya sendiri' dan tangane 'tangannya' pada (10a). Penggunaan satuan lingual - e pada jenenge 'namanya', tangane 'tangannya' merujuk pada pronominal ketiga sebagai pemiliknya. Dari uraian itu, jelas bahwa di dalam paragraf narasi (10) digunakan sudut pandang orang ketiga.

\section{PENGUNGKAPAN TUTURAN DALAM PARAGRAF NARASI}

Dalam penceritaan sebuah kisah, sang pengarang menggunakan dua cara, yaitu menggunakan tuturan langsung dan tidak langsung. Tuturan langsung adalah ungkapan atau ekspresi batin yang disampaikan atau diungkapkan secara langsung oleh tokoh dalam cerita. Dalam menceritakan sebuah kisah, seorang pengarang sering melukiskan komunikasi para tokoh dengan menggunakan tuturan langsung. Dengan kelangsungan tuturan itu, proses penceritaan menjadi hidup, berkekuatan tinggi dalam memikat perhatian pembaca. Selain itu, penceritaan sebuah kisah diciptakan oleh sang pengarang, bukan secara langsung dari para tokoh sebagai pemegang peran.

\section{Paragraf Narasi Tidak Bertuturan Langsung}

Paragraf narasi tidak selalu bertuturan langsung. Maksudnya, semua proposisi di dalam paragraf tersebut merupakan ekspresi pengarang yang menceritakan segala keadaan dan peristiwa yang dialami tokoh sebagai partisipannya. Dalam hal ini seorang pengarang atau penulis tidak membutuhkan deskripsi tuturan peristiwa yang dialami atau dilakukan partisipannya. Contohnya sebagai berikut.

(11) (a) Pasien iku nuduhake tangan kiwane. (b) Dhokter iku ujug-ujug ngguyu lakak-lakak. (c) Dheweke ujug-ujug nyekel tanganne pasiene kanthi kebak semangat. (d) Kanthi cepet dhokter naleni tangan iku banjur enggalenggal njupuk piranti. (Penjebar Semangat, 1996:28)

'(a) Pasien itu menunjukkan tangan kanannya. (b) Dokter itu tiba-tiba tertawa terbahakbahak. (c) Ia tiba-tiba memegangi tangan pasiennya dengan penuh semangat. (d) Dengan cepat dokter mengikat tangan itu lalu segera mengambil perabot.'

(12) (a) Inspektur Achmadi menyat ngadeg, marani kamare Kandar. (b) Kandar ditakoni lan diajak mlebu ngomah. (c) Wangsulane, mundhak karanta-ranta atine kelingan wong tuwane, amarga wiwit umur nem taun dheweke ora ngerti jenenge, mung fotone kang isih disimpen. (Kumpule Balung Pisah, 1966:160)

(a) Inspektur Achmadi segera berdiri, mendatangi kamar Kandar. (b) Kandar ditanya dan diajak masuk rumah. (c) Jawabannya, nanti malahan semakin bersedih 
hatinya teringat pada orang tuanya, lantaran sejak usia enam tahun ia tidak mengerti namanya, hanyalah fotonya yang masih tersimpan.'

Dalam PN (11) dan (12) dimuat kumpulan cerita yang pada setiap proposisinya tidak menggunakan tuturan langsung. Pengarang tidak secara langsung mendeskripsikan keadaan dan peristiwa yang dialami atau yang dilakukan tokoh sebagai partisipannya. Semua proposisi tentang keadaan dan peristiwa tokoh itu diceritakan melalui bahasa pengarang.

\section{Paragraf Narasi Bertuturan Langsung}

Dalam paragraf narasi yang bertuturan langsung terjadi kombinasi antara tuturan pengarang yang diungkapkan secara tidak langsung dan ungkapan tokoh yang dituturkan secara langsung. Tuturan tidak langsung ini dihasilkan oleh pengarang, sedangkan tuturan langsung dihasilkan oleh tokoh yang menjadi partisipannya. Tuturan langsung dalam paragraf narasi ini ada yang berpenanda dan tidak berpenanda. Untuk itu, perhatikan uraian berikut.

\section{Paragraf Narasi Bertuturan Langsung tidak Berpenanda}

Paragraf narasi berikut menggunakan tuturan langsung tidak berpenanda. Contohnya sebagai berikut.

(13) (a) Wong wadon ing ngarepe bendaraku mesem. (b) Banjur kanthi trampil tangane sing alus mbenerake dhasi, krah jas, lan clana sisih ngisor. (c) Aku kober disenggol uga.

"Menika rak sepatu ingkang mundhut kala emben ta, Pak?"

"Hiya."

"Pas sanget lho Pak."

"Lha witikna sing milihake bae pinter kok."

"Sanes ingkang milihaken ingkang pinter, nanging ingkang ngagem ingkang pancen saestu sembada." (Penjebar Semangat No. 33-15 Agustus 1998:29)

(a) Wanita yang berada di depan majikanku itu tersenyum. (b) Lalu dengan terampil tangannya yang halus menata dasi, krah jas, dan celana bagian bawah. (c) Aku sempat disentuh juga.

"Ini kan sepatu yang membeli saat itu ta, Pak?"

"Ya."

"Tepat sekali lo Pak."

"Habis ... yang memilihkan orangnya pintar sih."

"Bukan yang memilihkan yang pintar, tetapi yang memakai yang memang benar-benar gagah.”

Tuturan langsung pada (13) tersebut ditandai dengan tanda apit petik ganda. Tuturan tersebut menggambarkan secara langsung keadaan yang dialami atau peristiwa yang dijalani tokoh sebagai partisipannya. Tuturan langsung itu berada pada urutan sebelah kanan sesudah tuturan penceritaan pengarang. Tuturan langsung tersebut tidak berpenanda.

\section{Paragraf Narasi Bertuturan Langsung Berpenanda}

Paragraf narasi ini menggunakan tuturan langsung berpenanda. Penanda tuturan langsung itu berada di depan, di tengah, dan di belakang tuturan penceritaan pengarang. Penanda tuturan langsung ini biasanya menyatakan makna 'siar', misalnya kandha 'berkata', takon 'bertanya', alok 'menginformasikan', saruwe 'menyarankan', celathu 'berkata', dan sebagainya.

\section{Tuturan Langsung Berpenanda di Depan}

Penanda tuturan langsung (PTL) pada paragraf ini berada di antara tuturan pengarang dan tuturan tokoh sebagai partisipannya. PTL ini berada pada urutan sebelah kiri atau di depan tuturan langsung. Untuk itu, perhatikan contoh berikut.

(14) ... (d) Aku mesam-mesem, Daliman tanggap. (e) Mula sopir trek iki banjur celathu, "Jakarta nggih Bu?" $(f)$ Aku gedheg. Daliman sajak gela, pikirane mbok menawa bakal ngeterake barang ing Jakarta, nanging jebul ora. (Djaka Lodang No. 52, 1999:41)

... (d) Saya tersenyum, Daliman mengerti. (e) Oleh karena itu, sopir truk ini terus berkata, "Jakarta ya Bu?" (f) Aku menggelengkan kepala. Daliman sedikit kecewa, dia berpikir, siapa tahu disuruh 
mengantar barang ke Jakarta, ternyata tidak.'

Penanda tuturan langsung pada (14) berupa kalimat Mula sopir trek iki banjur celathu 'Maka sopir truk ini terus berkata' yang berada di depan tuturan langsung Jakarta nggih Bu? 'Jakarta nggih Bu?'. Tuturan langsung tersebut berisi gambaran keadaan atau peristiwa sebagai kelengkapan dari penceritaan pengarang sebelumnya.

\section{Tuturan Langsung Berpenanda di Tengah}

Penanda tuturan langsung ada yang berada di tengah kalimat, diapit tuturan langsung. Untuk itu, perhatikan contoh berikut.

(15) (a) Wusana dheweke menyang nggone ahli bedhah. "Dhokter," kumecape kanthi swara gemeter, "aku wis mutusake kepengin pisahan karo tanganku iki. ... (e) Mula, daksuwun Pak Dhokter kersa nugel tanganku iki." (Penjebar Semangat 1996:28)

"(a) Akhirnya ia ke tempat ahli bedah. "Dokter," ungkapnya dengan suara merintih, "Saya memutuskan berniat berpisah dengan tanganku. ... (e) Oleh sebab itu, saya mohon Pak Dokter bersedia memotong tanganku ini.'

(16) (a) "Aja kesusu dhisik," panyaruwe Dhokter, "awake dhewe aja nganti nglakokake prakara-prakara liyane. ... (c) Aku kuwatir yen iku kabeh mung saderma pancingan." (Penjebar Semangat 1996:28)

“"(a) Jangan terburu-buru,” kata Dokter, "kita jangan sampai melaksanakan hal-hal yang bukan pada tempatnya." ... (c) Saya khawatir kalau semua itu sebagai umpan."

Satuan kebahasaan yang berstatus sebagai penanda tuturan langsung pada paragraf (15) berupa kalimat Kumecape kanthi swara gumeter 'Ucapnya dengan suara gemetar', sedangkan penanda tuturan langsung pada (16) berupa frasa panyaruwe dhokter 'saran dokter'. Kedua penanda tuturan langsung itu berada di tengah-tengah atau diapit tuturan langsung.

\section{Tuturan Langsung Berpenanda di Belakang}

Penanda tuturan langsung pada bagian ini berada di belakang. Contohnya sebagai berikut.

(17) (a) "Pam, Pamungkas, yen dikandhani wong tuwa iku mbok ya nggugu. ... (f) Yen ora prei olehmu ngrokok, mbesuk yen ana apa-apa aja sambat marang aku" kandhane bapak bareng sumurup menawa aku isih rokokan. (Penjebar Semangat, 1990:56)

'(a) "Pam, Pamungkas, Kalau dinasihati orang tua itu mbok ya mau. ... (f) Kalau tidak mau berhenti merokok, besok kalau ada apa-apa jangan mengeluh kepadaku" kata bapak setelah mengetahui bahwa saya masih merokok.'

(18) (a) Wengine lumingsir sansaya sepi. (b) Langite katon peteng kinemulan mendhung ireng. (c) Ora sawetara suwe udan grimis riwis-riwis wiwit tumiba. Saeler rokok dak dudut saka bungkuse banjur dak templekke ing lambeku.

"Aku aja disumet dhisik," kandhane rokok kang dakakep iku bareng ngerti yen aku wus ngempakake erek.

"Kena apa kowe duwa kekarepanku. Awit awan mau geniku wus kepengin ngobong awakmu," sambungku kalem. (Penjebar Semangat, 1990:57)

' (a) Malam semakin sepi. (b) Langit tampak gelap tertutup mendung. (c) Tidak lama hujan gerimis rintik-rintik mulai turun. Sebatang rokok saya ambil dari bungkusnya lalu saya letakkan di bibirku.'

"Aku jangan dinyalakan dulu," kata rokok yang saya isap itu ketika melihat saya sudah menyalakan korek."

"Kenapa kamu menolak keinginanku. Dari siang tadi apiku sudah ingin membakar tubuhmu," sambungku tenang.'

Penanda tuturan langsung paragraf (17) tersebut berupa kalimat Kandhane Bapak bareng sumurup menawa aku isih rokokan. 'Kata Bapak setelah melihat bahwa saya masih merokok'. Adapun penanda tuturan langsung paragraf (18) berupa frasa sambungku kalem 'kataku tenang'. Kedua penanda tuturan langsung tersebut berada di belakang tuturan langsung.

Dari uraian tersebut jelas bahwa di dalam paragraf narasi ada yang menggunakan tuturan langsung dan ada yang tidak menggunakan tuturan langsung. Tuturan langsung itu ada yang berpenanda dan ada yang tidak berpenanda. Bagi paragraf yang bertuturan langsung berpenanda, penanda itu dapat berposisi di depan, di tengah, dan di belakang. 


\section{SIMPULAN}

Data menunjukkan bahwa paragraf narasi dalam bahasa Jawa dapat dikaji, sekurangkurangnya, berdasarkan tiga substansi, yaitu berdasarkan unsur yang membangunnya, kehadiran unsur penanda tuturan langsungnya, dan unsur yang menyatakan sudut pandang pengarangnya. Berdasarkan unsur yang membangunnya, paragraf narasi terdiri atas unsur partisipan dan unsur peristiwa. Di dalam unsur partisipan diisi dengan nomina persona atau yang dipersonifikasi yang berperan sebagai tokohnya. Unsur peristiwa diisi dengan serangkaian aktivitas yang biasanya dinyatakan dengan kategori verba, baik verba aksi, proses, maupun keadaan.

Sebagian besar paragraf narasi mengandung tuturan langsung, baik yang berpenanda maupun yang tidak berpenanda. Penanda tuturan langsung itu dapat berada di depan, di tengah, dan di akhir. Berdasarkan sudut pandangnya, paragraf narasi dibedakan atas sudut pandang orang pertama dan sudut pandang orang ketiga. Pada sudut pandang orang pertama $(\mathrm{O} 1)$, pencerita dapat berperan sebagai tokoh sentral atau tokoh utama, dapat juga sebagai pengamat. Di dalam paragraf narasi yang bertokoh sentral O1 lazim digunakan kata ganti $a k u$ 'aku, saya' atau klitika $-k u$ atau prefix takyang merujuk pada tokoh aku 'saya'. Selanjutnya, di dalam paragraf narasi yang bertokoh sentral O3 sering digunakan kata ganti dheweke 'ia, dia' atau klitika - $e$ atau -ne yang merujuk pada tokoh dheweke 'ia, dia'.

\section{DAFTAR RUJUKAN}

Baryadi, I. Praptomo. (1993). "Kesatuan Topik dalam Wacana Eksposisi, Wacana Deskripsi, dan Wacana Narasi” dalam Penyelidikan Bahasa dan Perkembangan Wawasannya. Jakarta: Masyarakat Linguistik Indonesia.

. (2002). Dasar-Dasar Analisis Wacana dalam Ilmu

Bahasa. Yogyakarta: Pustaka Gondho Suli.

Givon, Talmy (ed.) (1979). Sintax and Semantics

Volume 12. New York: Academic Press.
Grimes, Joseph E. (1975). The Thread of Discourse. The Hague: Mouton.

Indiyastini, Titik dkk. (2003). "Wacana Naratif dalam Bahasa Jawa. Yogyakarta: Departemen Pendidikan Nasional, Bagian Proyek Bahasa dan Sastra Indonesia dan daerah, Daerah Istimewa Yogyakarta.

Keraf, Gorys. (1982). Argumentasi dan Narasi. Jakarta: Gramedia Pustaka Utama.

Kesuma, Tri Mastoyo Jati. (2009). "Metode Linguistik Menurut Perspektif Dr. Sudaryanto" dalam P. Ari Subagyo (ed.) Peneroka Hakikat Bahasa. Yogyakarta: Penerbit Universitas Sanata Dharma.

Moeliono, Anton M. (1989). Kembara Bahasa: Kumpulan Karangan Tersebar. Jakarta: Penerbit PT Gramedia.

Montolalu, Lucy R. (1988). “Makna Hubungan Proposisi dalam Teks Bahasa Indonesia" dalam Kongres Bahasa Indonesia V 28 Oktober-2 November 1988. Jakarta: Departemen Pendidikan dan Kebudayaan.

Nardiati, Sri dkk. (2013). "Paragraf dalam Bahasa Jawa: Konstruksi dan Permasalahannya". Yogyakarta: Balai Bahasa Provinsi Daerah Istimewa Yogyakarta.

Peter dan Sheryl Silzer. (1977). "Discourse Considerations in Bahasa Indonesia" dalam Indonesia Quarterly. Vol. V. Nomor 3. CSIS. Halaman 72-110.

Poedjosoedarmo, Gloria dkk. (1981). Beberapa Masalah Sintaksis Bahasa Jawa. Jakarta: Departemen Pendidikan dan Kebudayaan.

Ramlan, M. (1993). Paragraf: Alur Pikiran dan Kepaduannya dalam Bahasa Indonesia. Yogyakarta: Penerbit Andi Offset.

Sudaryanto. (1982). Metode Linguistik. Yogyakarta: Fakultas sastra dan Kebudayaan, Universitas Gadjah Mada. (1993). Metode dan Teknik Analisis Bahasa: Pengantar Penelitian Wahana Kebudayaan secara Linguistis. Yogyakarta: Duta Wacana University Press.

Sukesti, Restu. (2011). Tema-Rema dalam Bahasa Jawa Ngoko Dialek Banyumas: Kajian Penataan Organisasi Informasi. Jurnal Humaniora, 23, 219228. 
Sumadi dkk. (1998). Kohesi dan Koherensi dalam Wacana Naratif Bahasa Jawa. Jakarta: Pusat Pembinaan dan Pengembangan Bahasa, Departemen Pendidikan dan Kebudayaan.

Tarigan, Djago. (1986). Membina Keterampilan Menulis Paragraf dan Pengembangannya. Bandung: Penerbit Angkasa.
Tampubolon, D.P. (1979). Tipe-Tipe Semantik Kata Kerja Bahasa Indonesia Kontemporer. Jakarta: Pusat Pembinaan dan Pengembangan Bahasa, Departemen Pendidikan dan Kebudayaan.

Wedhawati dkk. (2008). "Wacana Narasi Bahasa Jawa". Yogyakarta: Balai Bahasa Yogyakarta. 